\title{
Water Quality Index (WQI) for Main Source of Drinking Water (Karaçomak Dam) in Kastamonu City, Turkey
}

Idris Basher Imneisi* and Miraç Aydin

Department of Water Shed Management, Faculty of Forestry, Kastamonu University Graduate School of Natural and Applied Sciences, Kastamonu University, Kastamonu, Turkey

\begin{abstract}
Karaçomak Dam is main source of drinking water in Kastamonu city (Turkey) for this reason, In this study used Water quality index which provides a single value to express overall quality based on 13 variables that were determined during the period between September 2015 until July 2016. Sampling points chosen as described by first station at intake point of the drinking water supply for Kastamonu city, second station was opposite intake point of the drinking water supply about (449) $\mathrm{m}$ along at main dam. The parameters namely Electrical Conductivity (EC), pH, Temperature (T), Dissolved oxygen (DO), Turbidity (TUR), Total hardness (Ha), Total alkalinity, Ammonia nitrogen $\left(\mathrm{NH}_{4}-\mathrm{N}\right), \mathrm{Nitrite}$ nitrogen $\left(\mathrm{NO} \mathrm{O}_{2}-\mathrm{N}\right)$, Nitrate nitrogen $\left(\mathrm{NO}_{3}-\mathrm{N}\right)$, Phosphate $(\mathrm{PO}-\mathrm{P})$, Biochemical oxygen demand (BOD), Chemical oxygen demand (COD) were analyzed according to Standard Methods for the Examination of Water and Wastewater. The resulted WQI shows that (35.5 and 32.4) for sites (S1 and S2) respectively. On the other hand, there was significant temporal variations in water quality index among poor quality to excellent quality whereas that January 2016 showed high level of deterioration at $(\mathrm{S} 1, \mathrm{~S} 2)$, this may be due to starting the winter 2016 where high contribution from runoff at downstream areas which increase of deterioration body water in the Dam. The results clearly show that Water Quality index (WQI) was useful tool to obtain the right decision and evaluating water quality. In future, evaluation of water quality in Karaçomak dam should be given main priority of using the microbiological parameters with physico-chemical parameters in WQI calculations and to water quality monitoring.
\end{abstract}

Keywords: Water quality index; Physico-chemical parameters; Kastamonu; Karaçomak dam

\section{Introduction}

Ecosystem forms are a prime natural resource and valuable national resource and water. The Water sources is often mainly in types of streams, lakes, glaciers, rainfall or ground water. Water is one of the most essential elements for all existing organism on this planet earth. The quantity and quality of water both surface or ground water have been deteriorated as a result of some significant points such as growing population, industrialization and social process [1-4]. Water quality is defined as all an information of biological, chemical, and physical elements of water and their interaction to decide the suitable usage for water [5]. In fact, described water quality dependent on which kind of using. For example, water utilized for irrigation must be completely minimal in dissolved minerals to avoid salination of soils; water for recreation using should reach criteria for fecal coli forms; and potable water must be safe for drinking and cleaning [6-8]. Therefore, traditional method of water quality assessment can be described as the analysis of the biological, chemical, and physical properties of water in guide to natural quality, human health impacts, and wanted uses $[9,10]$. For instance, The Physico-chemical parameters and some metal concentrations were measured to determine the water quality of the Beyler Reservoir Kastamonu-Turkey that the reservoir has a considerably high quality water [11]. Furthermore, [12] studied an evaluation of lake Uluabat-Turkey. On the other hand, water quality monitoring of surface water will help protect our waterways from pollution. Likewise, the monitoring to our source water that the best way to understand and to avoid pollution problems [13]. According to [14] has done evaluate the impacts of seasonal differences on sampling points of Karasu-Sarmisakli Creeks and Kizilirmak River in KayseriTurkey. In general, Water Quality Index (WQI) is a statistical functional tool for simplifying, detailed and describing complex information collected from any body of water which reflects the integrated influence on the overall quality variables this value is understandable and use by the decision makers, planer and the general public $[15,16]$. So, quality index (WQI), which is one of the most successful methods to describe the quality of water. Actually, many of WQIs using different variables relying on the water quality goals all over the world $[10,17]$. The Karaçomak dam is the most very important water supply in the Kastamonu of Turkey and Karaçomak Dam plays an important role in water supply which was built in 1973 helps as the major source of water for residents of Kastamonu Municipality in Upper North Region of Turkey. Water dam stored in reservoir tanks and then distributed to residents through distribution pipe lines after treated by the Kastamonu Water Company. But, some residents in neighborhoods the dam resort to the untreated water from the dam as their source of drinking water particularly when they go to their farms.

The objective of this study was to create a WQI for the water in the Karaçomak dam located in Kastamonu, turkey. These results are of vital importance to local residents who will have a general knowledge of the water quality in their region during a specific period of time, instead of attempting to understand complex water quality data. For the same objective, an annual spatiotemporal difference of water quality indices of the surface waters around the capital city of Turkey, Ankara, is evaluated using the CWQI, OWQI [18]. At the same time,

*Corresponding author: Idris Basher Imneisi, Department of Water Shed Management, Faculty of Forestry, Kastamonu University Graduate School of Natural and Applied Sciences, Kastamonu University, Kastamonu, Turkey, Tel: 00905456470241; E-mail: Idrisimneisi@yahoo.com

Received September 10, 2016; Accepted September 26, 2016; Published September 30, 2016

Citation: Imneisi IB, Aydin M (2016) Water Quality Index (WQI) for Main Source of Drinking Water (Karaçomak Dam) in Kastamonu City, Turkey. J Environ Anal Toxicol 6: 407. doi: 10.4172/2161-0525.1000407

Copyright: $\odot 2016$ Imneisi IB, et al. This is an open-access article distributed under the terms of the Creative Commons Attribution License, which permits unrestricted use, distribution, and reproduction in any medium, provided the original author and source are credited. 
Citation: Imneisi IB, Aydin M (2016) Water Quality Index (WQI) for Main Source of Drinking Water (Karaçomak Dam) in Kastamonu City, Turkey. J Environ Anal Toxicol 6: 407. doi: 10.4172/2161-0525.1000407

Page 2 of 8

using this index will provide important information to decision makers as to whether it is a benchmark-success or failure.

\section{Materials and Methods}

\section{Description of the study area}

The study area is the main source of drinking water for Kastamonu area where exist Karaçomak dam. Geographically, Karaçomak dam is located at latitudes $\left(41^{\circ} 19^{\prime} 07.56^{\prime \prime}\right.$ to $\left.41^{\circ} 17^{\prime} 29.27^{\prime \prime} \mathrm{N}\right)$, and longitudes $\left(33^{\circ} 44^{\prime} 41.38^{\prime \prime}-33^{\circ} 44^{\prime} 06.32^{\prime \prime} \mathrm{E}\right)$ in Kastamonu city, Turkey, and elevated 887-904 $\mathrm{m}$ above sea level. In an attempt to continue to the proposed aims of this study, two sites were chosen for sample collection at the study area (Figure 1).

Site one (S1) was selected from Karaçomak dam at the intake of the drinking water supply for Kastamonu city with a GPS coordinates and elevation of $\left(41^{\circ} 19^{\prime} 05.84^{\prime \prime} \mathrm{N}\right.$ and - $\left.33^{\circ} 44^{\prime} 35.56^{\prime \prime} \mathrm{E}-893 \mathrm{~m}\right)$. Site two (S2) was opposite the intake of the drinking water supply for Kastamonu city with GPS coordinates and elevation of $\left(41^{\circ} 18^{\prime} 59.63^{\prime \prime} \mathrm{N}\right.$ and $-33^{\circ}$ 44' 51.04 " E-897 m) The overall distance between the sample site S1 to sample site S2 was about (449) $\mathrm{m}$ along at main dam.

\section{Sampling and sample preparation}

Water samples were taken from two sites every two months starting in September 2015 until July 2016. Samples were collected at $30 \mathrm{~cm}$ depth from the surface: All measurements were carried out in triplicate, and the results were expressed as averages. The measurement at sampling site, Dissolved oxygen, Electric conductivity, Turbidity, $\mathrm{pH}$ and water temperature were recorded. The water samples were held in ice boxes and immediately transported to laboratory of Kastamonu university for analysis of water quality following common protocols.

\section{Sample analysis}

Electrical conductivity (EC), $\mathrm{pH}$, temperature $(\mathrm{T})$ and dissolved oxygen (DO) were measured locally by (HQ40d Portable $\mathrm{pH}$, Conductivity, Dissolved Oxygen Multi-Parameter Meter) field instruments (Hach Company). Turbidity (TUR) was measured using WTW Turb 430 IR model with highest precision according to US EPA for water analytics, quality control and process monitoring. Total hardness $(\mathrm{Ha})$ and total alkalinity were determined by volumetric titrimetry. Ammonia nitrogen $(\mathrm{NH} 4-\mathrm{N})$, nitrite nitrogen $(\mathrm{NO} 2-\mathrm{N})$, nitrate nitrogen (NO3-N), Phosphate (PO4-P) were determined using a HACH-DR 6000 UV-Vis Spectrophotometer. Biochemical oxygen demand (BOD) was determined by five days incubation and chemical

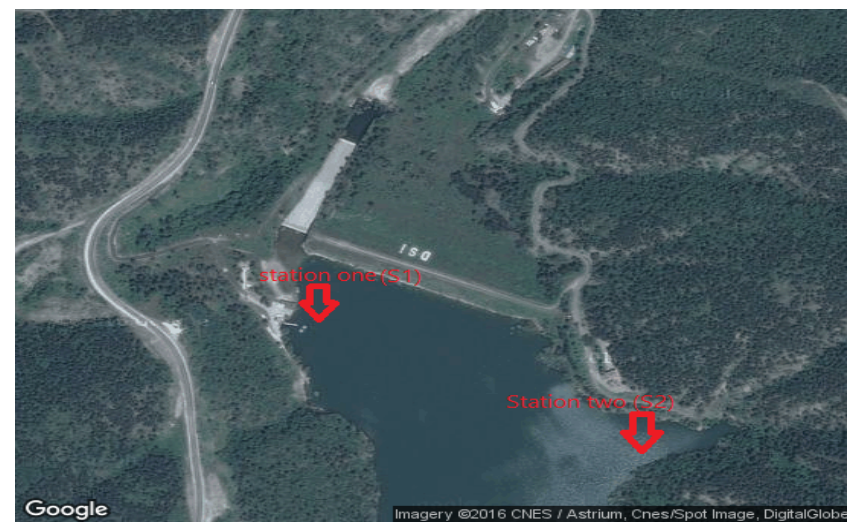

Figure 1: Karaçomak dam shows location of sample collection at the study area. oxygen demand (COD) with open reflux method. All of the water quality parameters were analyzed according to Standard Methods for the Examination of Water and Wastewater [19,20].

\section{Technique of water quality index (WQI)}

The statistical analysis was done for descriptive statistics using (SPSS Version 19.0 for Windows 2008). Table 1 shown the statistics of the Physico-Chemical Parameters in Karaçomak dam.

The computation of the WQI, the weighted arithmetic index method of the parameter was implemented from many literatures [21-23].

The WQI considered is of the form:

$$
W Q I=\sum_{i=1}^{n} \frac{W i q i}{\sum W i}
$$

$\mathrm{qi}=$ Quality rating for the $\mathrm{i}^{\text {th }}$ water quality parameters

Wi: Unit weight for the $\mathrm{i}^{\text {th }}$ parameters

For doing the calculation of WQI in this study requires four steps:

- Firstly step is parameter selection thirteen variables were selected to calculate the WQI utilizing the standards of drinking water quality recommended by the World Health Organization (WHO) and Water Pollution Control Statement of Regulation Turkish (WPCSR) shown Table 1 (Amendment Table 1: RG13/2/2008-26786) [24].

- Secondly step is Computation of sub index of quality rating (qi)

According to Brown et al., quality rating or sub index (qi) was calculated using the following

expression: $q_{i}=\left(\frac{\left(\mathrm{V}_{\mathrm{a}}-\mathrm{V}_{\mathrm{i}}\right)}{\left(\mathrm{V}_{\mathrm{s}}-\mathrm{V}_{\mathrm{i}}\right)}\right) \times 100$

$\mathrm{q}_{\mathrm{i}}=$ Quality rating for the $\mathrm{i}^{\mathrm{ith}}$ water quality parameters

$\mathrm{V}_{\mathrm{a}}$ : actual value present of the $\left(\mathrm{i}^{\text {th }}\right)$ parameter at a given sampling station.

$\mathrm{V}_{\mathrm{i}}$ : ideal value ( 0 for all parameters excepts $\mathrm{pH}$ and $\mathrm{DO}$ which are 7.0 and $14.6 \mathrm{mg} /$ lit respectively).

\section{$\mathrm{V}_{\mathrm{s}}$ : standard value}

If quality rating=zero that means complete absence of pollutants. While, quality rating $0<\mathrm{q}_{\mathrm{i}}<100$ implies that, the pollutants are above the standards [25].

- Thirdly step is Computation of unit weight (relative weight calculation)

The Unit weight $\left(\mathrm{W}_{\mathrm{i}}\right)$ to different water Quality parameters are inversely relative to the recommended standards value for the related parameters.

$$
W_{i}=\frac{k}{s_{i}}
$$

$\mathrm{w}_{\mathrm{i}}$ : unit weight for the $\mathrm{i}^{\text {th }}$ parameters

$\mathrm{s}_{\mathrm{i}}$ : standards value for the $\mathrm{i}^{\text {th }}$ parameters

k: relative constant

This value considered (1) here, also can calculate using the following equation: 
Citation: Imneisi IB, Aydin M (2016) Water Quality Index (WQI) for Main Source of Drinking Water (Karaçomak Dam) in Kastamonu City, Turkey. J Environ Anal Toxicol 6: 407. doi: 10.4172/2161-0525.1000407

Page 3 of 8

\begin{tabular}{|c|c|c|c|c|c|c|c|}
\hline \multirow[t]{2}{*}{ Parameters } & \multirow[t]{2}{*}{ Standard values } & \multicolumn{3}{|c|}{ Station (S1) $n=18$} & \multicolumn{3}{|c|}{ Station (S2) $n=18$} \\
\hline & & Min & Max & Std. Dev. & Min & Max & Std. Dev. \\
\hline EC & 1500 & 431 & 471 & 12.69 & 419 & 475 & 16.99 \\
\hline $\mathrm{pH}$ & $6.5-8.5$ & 8.51 & 8.77 & 0.07 & 8.48 & 8.91 & 0.14 \\
\hline Temperature & 25 & 5.3 & 19.8 & 5.57 & 4.7 & 19.5 & 5.7 \\
\hline Turbidity & $5 \mathrm{NTU}(\mathrm{WHO})$ & 2.0 & 7.5 & 1.7 & 2.4 & 8.4 & 1.9 \\
\hline T. Hardness & 500 & 91.8 & 97.7 & 1.7 & 91.6 & 95.4 & 1.13 \\
\hline Alkalinity & 120 (WPCSR) & 28.5 & 29.3 & 0.2 & 28.1 & 30.1 & 0.71 \\
\hline DO & 8 (WPCSR) & 7.3 & 11.8 & 1.7 & 6.4 & 12.9 & 2.1 \\
\hline BOD & 4 (WPCSR) & 2.1 & 16.1 & 5.07 & 2.56 & 19.3 & 6.06 \\
\hline COD & 25 (WPCSR) & 2.1 & 15.4 & 4.3 & 3.7 & 24.9 & 7.39 \\
\hline $\mathrm{NH}_{4}-\mathrm{N}$ & 0.2 (WPCSR) & 0.025 & 0.136 & 0.033 & 0.023 & 0.138 & 0.040 \\
\hline $\mathrm{NO}_{3}-\mathrm{N}$ & 5 (WPCSR) & 0.09 & 0.7 & 0.182 & 0.09 & 0.65 & 0.172 \\
\hline $\mathrm{NO}_{2}-\mathrm{N}$ & $1(\mathrm{WHO})$ & 0.004 & 0.013 & 0.0025 & 0.001 & 0.01 & 0.002 \\
\hline $\mathrm{PO}_{4}-\mathrm{P}$ & $0.1(\mathrm{WHO})$ & 0.02 & 0.11 & 0.029 & 0.01 & 0.090 & 0.025 \\
\hline
\end{tabular}

Table 1: Statistics of chemical parameters (all in $\mathrm{mg} / \mathrm{l}$ and $\mathrm{EC}$ in $\mu \mathrm{S} / \mathrm{cm}$ ) in Karaçomak dam.

\begin{tabular}{|c|c|c|}
\hline WQI Value & Rating of water quality & \\
\hline $0-25$ & Excellent water quality & Grading \\
\hline $26-50$ & Good water quality & A \\
\hline $51-75$ & Poor water quality & B \\
\hline $76-100$ & Very poor water quality & C \\
\hline Above 100 & Unsuitable for drinking purpose & \\
\hline
\end{tabular}

Table 2: The levels of water quality index.

\begin{tabular}{|c|c|c|c|c|c|c|c|c|c|c|c|c|c|}
\hline \multirow[t]{2}{*}{ Parameters } & \multirow[t]{2}{*}{ Standard values } & \multicolumn{6}{|c|}{ Station (S1) } & \multicolumn{6}{|c|}{ Station (S2) } \\
\hline & & Sep & Nov & Jan & March & May & July & Sep & Nov & Jan & March & May & July \\
\hline $\mathrm{pH}$ & $6.5-8.5$ & 8.59 & 8.67 & 8.55 & 8.75 & 8.66 & 8.64 & 8.69 & 8.59 & 8.49 & 8.87 & 8.86 & 8.74 \\
\hline EC & 1500 & 439.6 & 459.0 & 465.6 & 448.3 & 436.6 & 434 & 432.3 & 458.3 & 469 & 440 & 423.3 & 430.6 \\
\hline Temperature & 25 & 19.4 & 10.5 & 5.7 & 5.5 & 11.7 & 18.1 & 19.4 & 10.1 & 4.9 & 5.26 & 11.2 & 17.6 \\
\hline T. Hardness & 500 & 92.7 & 91.9 & 96.9 & 95.8 & 93.9 & 93.75 & 94.3 & 91.86 & 95.1 & 95 & 94 & 94.01 \\
\hline $\mathrm{NH}_{4}-\mathrm{N}$ & 0.2(WPCSR) & 0.027 & 0.1 & 0.13 & 0.081 & 0.076 & 0.089 & 0.026 & 0.095 & 0.13 & 0.024 & 0.086 & 0.089 \\
\hline $\mathrm{NO}_{3}-\mathrm{N}$ & 5(WPCSR) & 0.09 & 0.27 & 0.3 & 0.32 & 0.37 & 0.68 & 0.1 & 0.19 & 0.31 & 0.38 & 0.39 & 0.6 \\
\hline $\mathrm{NO}_{2}-\mathrm{N}$ & $1(\mathrm{WHO})$ & 0.004 & 0.008 & 0.011 & 0.007 & 0.006 & 0.004 & 0.003 & 0.007 & 0.008 & 0.006 & 0.004 & 0.003 \\
\hline $\mathrm{PO}_{4}-\mathrm{P}$ & 0.65(WPCSR) & 0.08 & 0.10 & 0.046 & 0.021 & 0.039 & 0.07 & 0.07 & 0.086 & 0.05 & 0.016 & 0.03 & 0.069 \\
\hline Alkalinity & 120(WPCSR) & 28.9 & 29.04 & 28.9 & 29.1 & 28.6 & 28.7 & 29.4 & 28.83 & 29.9 & 28.5 & 28.1 & 29.8 \\
\hline Turbidity & 5NTU(WHO) & 2.75 & 2.72 & 2.13 & 7.05 & 4.18 & 3.26 & 3.1 & 2.65 & 2.52 & 8.01 & 3.44 & 3.48 \\
\hline DO & 8 (WPCSR) & 7.41 & 7.42 & 8.59 & 11.45 & 11.49 & 10.02 & 7.47 & 6.45 & 9.46 & 12.5 & 11.13 & 10.3 \\
\hline COD & 25 (WPCSR) & 15.2 & 8.4 & 6.42 & 10.0 & 2.7 & 3.23 & 24.7 & 6.63 & 3.65 & 12.1 & 4.36 & 7.4 \\
\hline BOD & 4 (WPCSR) & 4.6 & 2.9 & 15.56 & - & 2.53 & 3.87 & 6.17 & 7.15 & 19.0 & - & 2.63 & 4.1 \\
\hline
\end{tabular}

All the Parameters Value are Expressed in mg/l; Except $\mathrm{pH}$, Turbidity (NTU), Conductivity EC $\left(\mu \mathrm{sm}^{-1}\right)$

Table 3: Average the Physico-Chemical Parameters Water throughout the Study Period from September 2015-July 2016 for Karaçomak dam.

$$
k=\frac{1}{\sum\left[\frac{1}{s i}\right]}
$$

- Fourthly step is the computed WQI values are categorized into five groups is given in Table 2 which The levels of water quality index, the best value of water quality was given a low range and the bad levels a higher number [26].

\section{Results and Discussion}

The statistical analysis of the surface water of Karaçomak Dam was done to determine the chemical parameters that are deviating from WHO drinking water standard and Water Pollution Control Statement of Regulation Turkish (WPCSR) shown Tables 1 and 3. It was observed that the mean, min, max and Standard deviation for all parameters in the untreated surface water in Karaçomak dam.

\section{The physicochemical variables of water quality}

The physicochemical variables of water quality were analyzed using standard methods given in APHA (American Public Health Association) that were within the limits of the standard used. however, with exception of ( $\mathrm{pH}$, Turbidity, DO, BOD and PO4-P) had exceeded the acceptable limits of the standard in some months during the study period. Analytical outcomes obtained for various study variables at two sites in different times of the year 2015-2016 are summarized in Table 3 are discussed below (Figures 2-15).

The $\mathrm{pH}$ of natural water is the greatest point of the water quality and the extent contamination in the watershed areas. results obtained from the current study showed that kept between 8.49 and 8.87 and decreased relatively at January compared with average concentration of $\mathrm{pH}$ in march and April (rainy season) demonstrates a gradual increase probably due to runoff from farming area and photosynthetic activity during spring period at watershed of Karaçomak dam [27]. The average of EC values for the researched durations ranged between ( 423.3 to $465.6 \mu \mathrm{S} \mathrm{cm}^{-1}$ ) at sites S1 and S2. Table 3 which were lower than the recommended level $\left(1500 \mu \mathrm{S} \mathrm{cm}^{-1}\right)$ by Water Pollution Control Statement of Regulation Turkish (WPCSR) (Amendment Table 1: 
Citation: Imneisi IB, Aydin M (2016) Water Quality Index (WQI) for Main Source of Drinking Water (Karaçomak Dam) in Kastamonu City, Turkey. J Environ Anal Toxicol 6: 407. doi: 10.4172/2161-0525.1000407

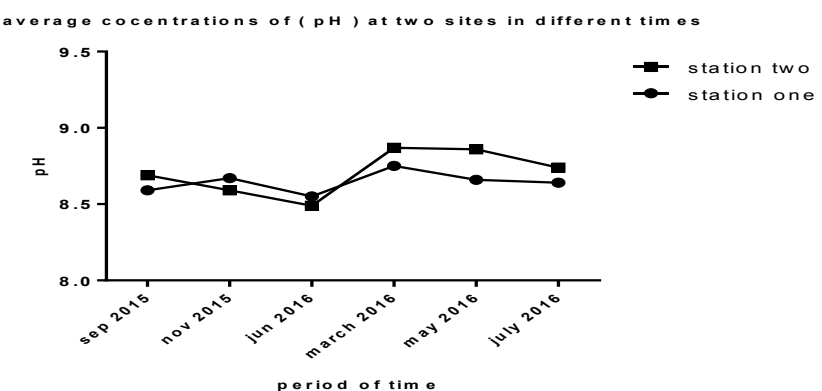

Figure 2: Average concentration of $(\mathrm{pH})$

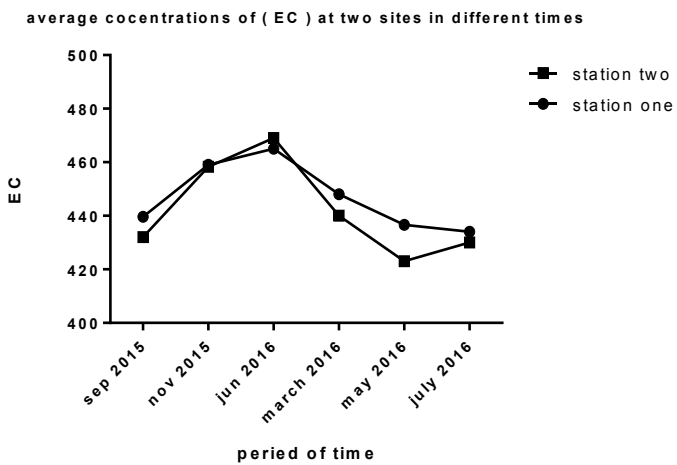

Figure 3: Average concentration of (EC)

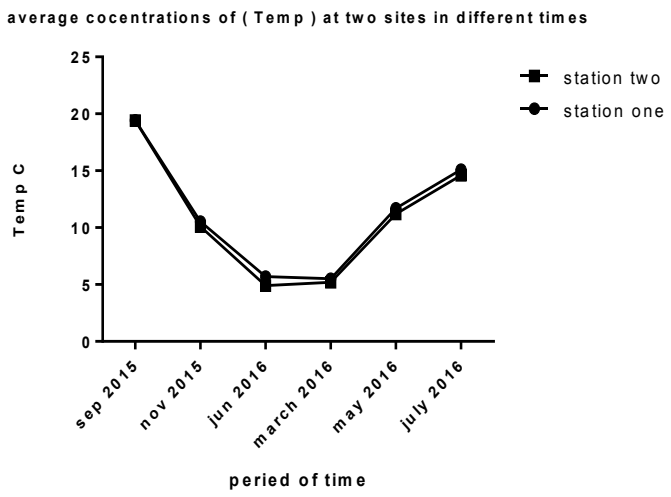

Figure 4: Average concentration of (Temp).

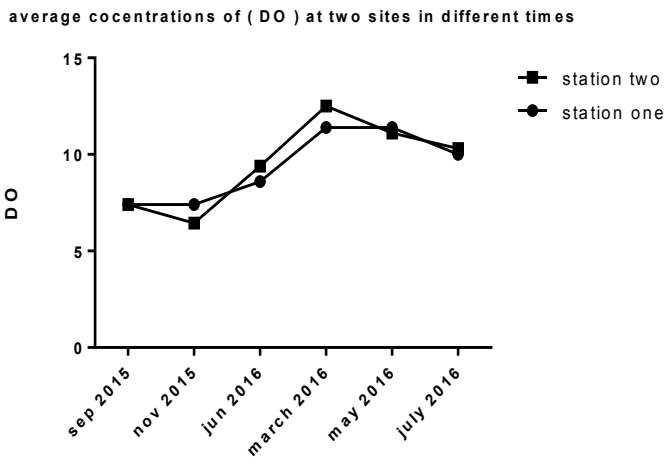

peried of time

Figure 5: Average concentration of (DO).

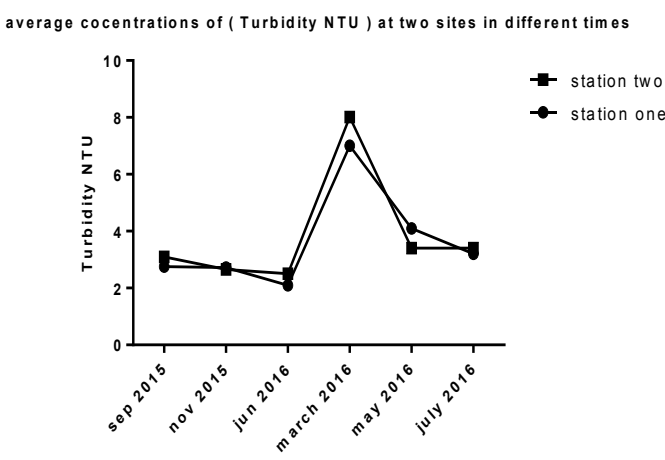

peried of time

Figure 6: Average concentration of (Turbidity).

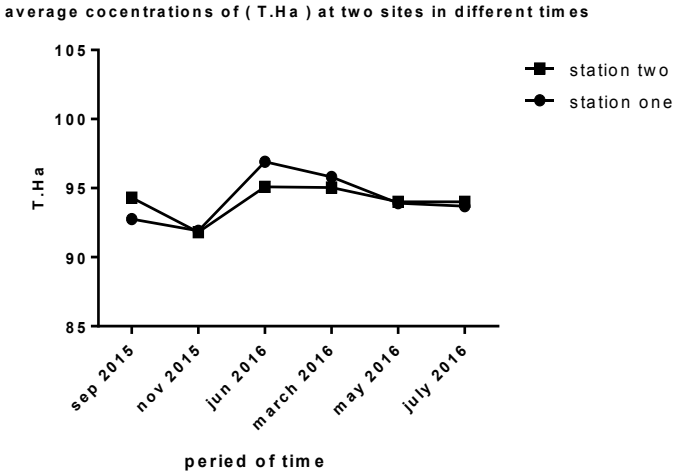

Figure 7: Average concentration of (T.Ha).

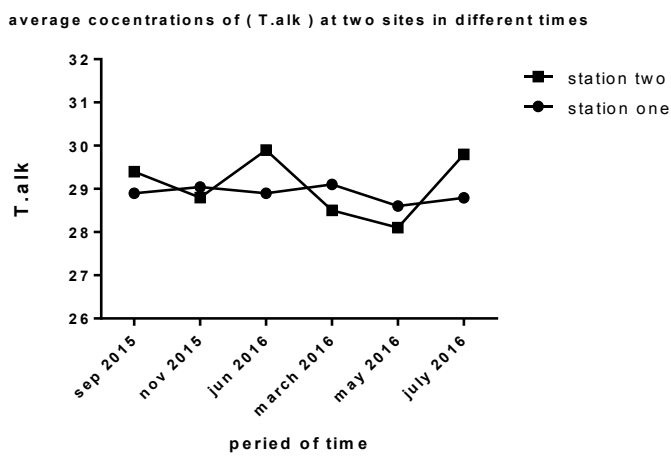

Figure 8: Average concentration of (T.alk).

RG-13/2/2008-26786) and WHO [24]. The results demonstrated those waters were suitable for drinking according on WHO $(1500 \mu \mathrm{S}$ $\mathrm{cm}^{-1}$ ) [24]. Water temperature value and dissolved oxygen value are an important points to determining the water quality. in the Figure 4. The Water temperature values increased in July and September with $\left(19.4^{\circ} \mathrm{C}, 17.6^{\circ} \mathrm{C}\right)$ compared to other months with $\left(4.9^{\circ} \mathrm{C}, 5.5^{\circ} \mathrm{C}\right)$. In contrast, the average dissolved oxygen in the Figure 5 was reduced during July, September, November with (10.3 mg/l, $7.4 \mathrm{mg} / \mathrm{l}, 6.45 \mathrm{mg} / \mathrm{l})$ which may be due to the rate of biodegradation and biological activity increases with the increase in the water temperature. In this study DO values noticed in Karaçomak Dam decreased in summer months while they increased in rainy season. Alike discovering was also mentioned for lake Pamvotis (Greece) by [28]. Turbidity of water Figure 6 at sites 
Citation: Imneisi IB, Aydin M (2016) Water Quality Index (WQI) for Main Source of Drinking Water (Karaçomak Dam) in Kastamonu City, Turkey. J Environ Anal Toxicol 6: 407. doi: 10.4172/2161-0525.1000407

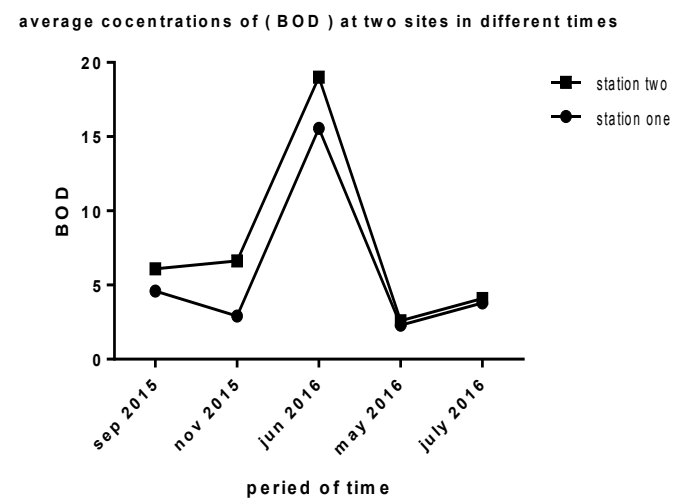

Figure 9: Average concentration of (BOD).

\section{average cocentrations of $(C O D)$ at two sites in different times}

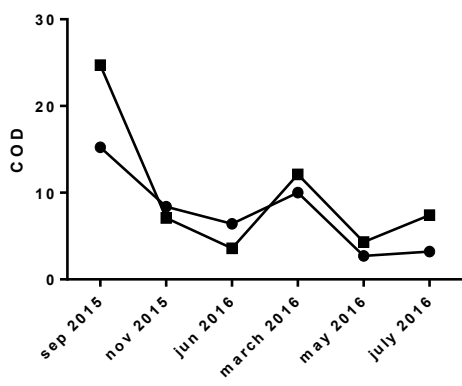

peried of time

Figure 10: Average concentration of (COD)

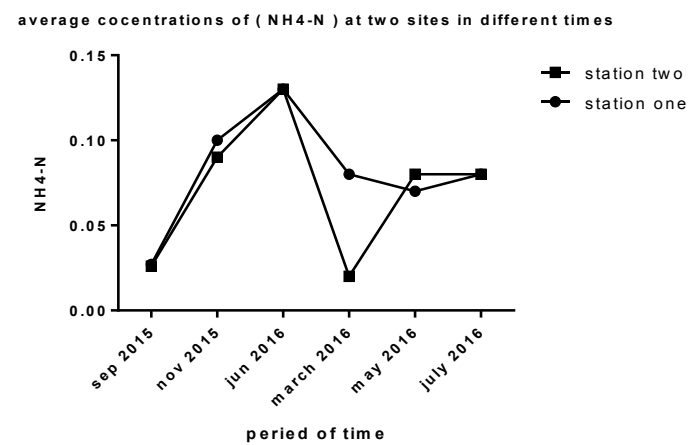

Figure 11: Average concentration of $\left(\mathrm{NH}_{4}-\mathrm{N}\right)$

average cocentrations of ( NO3-N) at two sites in different times

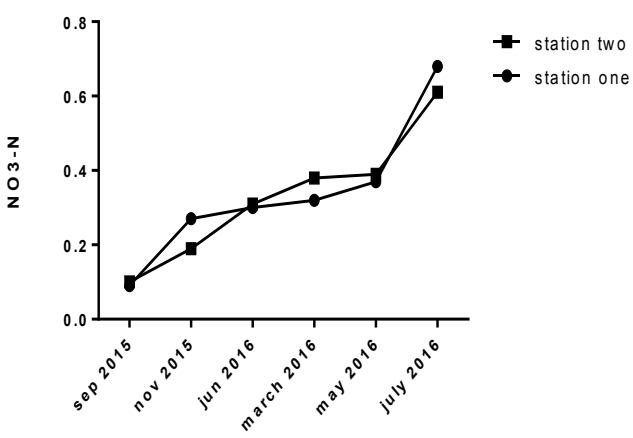

Figure 12: Average concentration of $\left(\mathrm{NO}_{3}-\mathrm{N}\right)$.

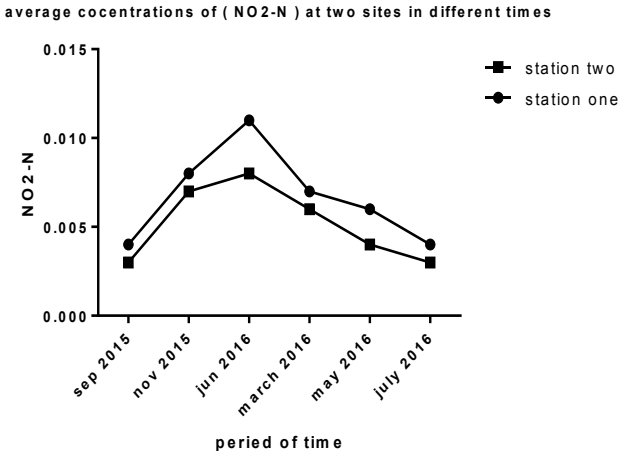

Figure 13: Average concentration of $\left(\mathrm{NO}_{2}-\mathrm{N}\right)$.

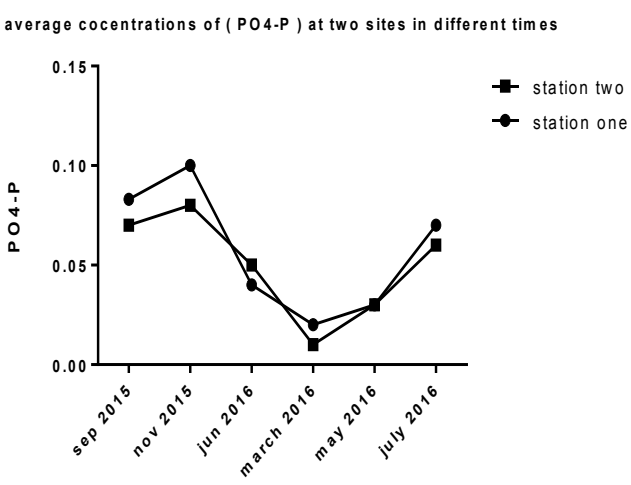

peried of time

Figure 14: Average concentration of (PO4-P).

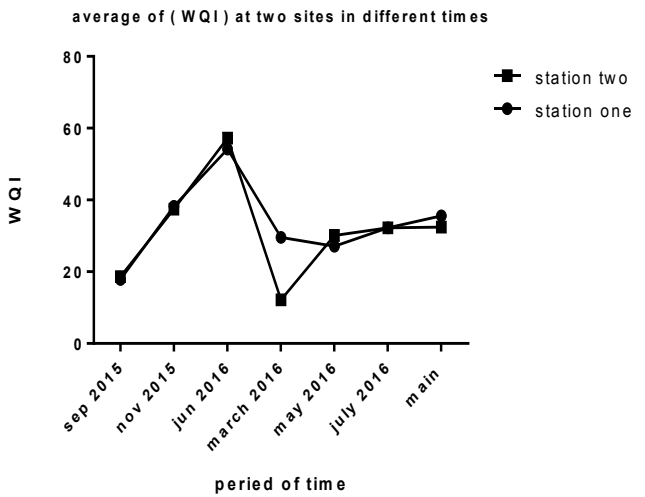

Figure 15: Average concentration of (WQI)

S1 and S2 shows that turbidity was higher in the March with 6.70 NTU and then it was lowered to reach levels of $2.13 \mathrm{NTU}$ averaged during other months of the year. The turbidity comes from clay particles within the eroded soil in any catchment area this is because after the rainfall events the water is rich in organic matter and clay particles. The hardness of water is generally determined by the amount of calcium and magnesium salt. Hardness level of water is associated to geological construction contact throughout watershed [12]. hardness values in water samples ranged from $91.6 \mathrm{mg} / \mathrm{l}$ to $97.7 \mathrm{mg} / \mathrm{l}$ with a mean value close to $94.1 \mathrm{mg} / \mathrm{l}$ according to Table 3 and Figure 7 which were within the acceptable limit of WHO, and WPCSR. Total alkalinity are below the permissible limits of WHO standards according to Table 3. BOD is 
Citation: Imneisi IB, Aydin M (2016) Water Quality Index (WQI) for Main Source of Drinking Water (Karaçomak Dam) in Kastamonu City, Turkey. J Environ Anal Toxicol 6: 407. doi: 10.4172/2161-0525.1000407

Page 6 of 8

a factor to evaluate the organic load in a water body. BOD levels, which evaluates the concentration of labile organic matter, demonstrated little spatial or temporal difference according to Table 1 which starting from $2.1 \mathrm{mg} / \mathrm{l}$ to $16.1 \mathrm{mg} / \mathrm{l}$ in the $\mathrm{S} 1$ (average $5.89 \mathrm{mg} / \mathrm{l}$ ) and $2.56 \mathrm{mg} / \mathrm{l}$ $19.3 \mathrm{mg} / \mathrm{l}$ in the S2 (average $7.7 \mathrm{mg} / \mathrm{l}$ ). The maximum value of BOD was recorded in start January 2016 at both S1 and S2 The results in January 2016 shows those waters were unsuitable for drinking according on WPCSR $(4 \mathrm{mg} / \mathrm{l})$ due to runoff from farming area at watershed in start the winter season. COD is one of the more utilized aggregate variables in environmental pollution. as mentioned in Table 3 which were within the acceptable limit by Water Pollution Control Statement of Regulation Turkish (WPCSR). The higher limit of COD concentration was in September with $25 \mathrm{mg} / \mathrm{l}$ at S2. Increases in COD might be due to an increase in chemical pollutants from runoff of farming area. The samples in Table 1 demonstrated to low variations in averaged ammonia (NH4-N) contents, from $0.027 \mathrm{mg} / \mathrm{l}$ to $0.13 \mathrm{mg} / \mathrm{l}$. Nitrate and Nitrite are interconnected, this really is due to contamination by human or animal waste as well as fertilizer run-off [24,29]. The nitrate (NO3-N) value varies from 0.09 to $0.6 \mathrm{mg} / \mathrm{l}$ was very low in study area, they fall below the (WHO) which was $10 \mathrm{mg} / \mathrm{l}$ NO3-N. Likewise,
Nitrite concentration was unimportant and no real pattern was noticed in concentration. Phosphate are chemical substances founded from the elements phosphorous and oxygen, they could be an important for plant and animal growth. Phosphor is actually in waters in some phosphate forms. Dissolved reactive phosphate (orthophosphate PO4-P) is the only phosphate substance that might be used by many plants and organisms [30]. The phosphate values (po4-p) obtained were within permissible limit $(0.65 \mathrm{mg} / \mathrm{l})$ for (WPCSR). The lower limit and upper limit values were $(0.021 \mathrm{mg} / \mathrm{l}$ and $0.08 \mathrm{mg} / \mathrm{l})$ for sites (S1 and S2) respectively, which recommend that phosphorus is not often noticed in high concentrations in waters as it is actually used up by plants.

\section{The water quality index analyses}

WQI is created by using the measurement of some important physicochemical variables of the surface water. The values of some physicochemical parameters for the calculation of WQI are presented in Tables 4 and 5. In addition, Table 6 displays in summary of WQI value from $(\mathrm{S} 1, \mathrm{~S} 2)$ for every two month starting in September 2015 to July 2016 was calculated to be inside range of poor water and good

\begin{tabular}{|c|c|c|c|c|c|c|}
\hline \multirow[t]{2}{*}{ NUM } & \multicolumn{6}{|c|}{ Station (S1) } \\
\hline & Parameters & Standard values & Unit Weight (Wn) & Observed Values & Quality Rating (qn) & Weighted (Wn.qn) \\
\hline 1 & EC & 1500 & 0.000078 & 447 & 29.8 & 0.00232 \\
\hline 2 & $\mathrm{pH}$ & $6.5-8.5$ & 0.013764 & 8.6 & 77.647 & 1.068 \\
\hline 3 & Temperature & 25 & 0.00468 & 11.85 & 47.4 & 0.2218 \\
\hline 4 & Turbidity & 5NTU(WHO) & 0.0234 & 3.68 & 73.6 & 1.7222 \\
\hline 5 & T. Hardness & 500 & 0.000234 & 94.19 & 18.83 & 0.0044 \\
\hline 6 & Alkalinity & 120(WPCSR) & 0.000975 & 28.92 & 24.1 & 0.0234 \\
\hline 7 & DO & 8 (WPCSR) & 0.014625 & 9.39 & 78.93 & 1.1544 \\
\hline 8 & BOD & 4 (WPCSR) & 0.02925 & 5.89 & 147.25 & 4.307 \\
\hline 9 & COD & 25 (WPCSR) & 0.00468 & 7.67 & 30.68 & 0.1435 \\
\hline 10 & $\mathrm{NH}_{4}-\mathrm{N}$ & 0.2 (WPCSR) & 0.585 & 0.085 & 42.5 & 24.86 \\
\hline 11 & $\mathrm{NO}_{3}-\mathrm{N}$ & 5 (WPCSR) & 0.0234 & 0.34 & 6.8 & 0.1591 \\
\hline 12 & $\mathrm{NO}_{2}-\mathrm{N}$ & $1(\mathrm{WHO})$ & 0.117 & 0.007 & 0.7 & 0.0819 \\
\hline 13 & $\mathrm{PO}_{4}-\mathrm{P}$ & 0.65 (WPCSR) & 0.18 & 0.062 & 9.53 & 1.716 \\
\hline \multicolumn{7}{|l|}{$\sum W_{n}=0.998$} \\
\hline \multicolumn{7}{|c|}{$W Q I=\sum_{i=1}^{n} \frac{W i q i}{\sum W i}=\frac{35.46}{0.997}=$} \\
\hline
\end{tabular}

Table 4: The computation of Water Quality Index of station (S1).

\begin{tabular}{|c|c|c|c|c|c|c|}
\hline \multirow[t]{2}{*}{ NUM } & \multicolumn{6}{|c|}{ Station (S2) } \\
\hline & Parameters & Standard values & Unit Weight (Wn) & Observed Values & Quality Rating (qn) & Weighted (Wn.qn) \\
\hline 1 & $\mathrm{EC}$ & 1500 & 0.000078 & 42 & 29.46 & 0.00229 \\
\hline 2 & $\mathrm{pH}$ & $6.5-8.5$ & 0.013764 & 8.71 & 88.647 & 1.2202 \\
\hline 3 & Temperature & 25 & 0.00468 & 11.42 & 45.68 & 0.21378 \\
\hline 4 & Turbidity & 5NTU (WHO) & 0.0234 & 3.88 & 77.6 & 1.8158 \\
\hline 5 & T. Hardness & 500 & 0.000234 & 94.07 & 18.81 & 0.0044 \\
\hline 6 & Alkalinity & 120 (WPCSR) & 0.000975 & 29.12 & 24.26 & 0.02366 \\
\hline 7 & DO & 8 (WPCSR) & 0.014625 & 9.5 & 77.27 & 1.1301 \\
\hline 8 & BOD & 4 (WPCSR) & 0.02925 & 7.72 & 193 & 5.645 \\
\hline 9 & COD & 25 (WPCSR) & 0.00468 & 9.92 & 39.68 & 0.1857 \\
\hline 10 & $\mathrm{NH}_{4}-\mathrm{N}$ & 0.2 (WPCSR) & 0.585 & 0.07 & 35 & 20.475 \\
\hline 11 & $\mathrm{NO}_{3}-\mathrm{N}$ & 5 (WPCSR) & 0.0234 & 0.33 & 6.6 & 0.1544 \\
\hline 12 & $\mathrm{NO}_{2}-\mathrm{N}$ & $1(\mathrm{WHO})$ & 0.117 & 0.005 & 0.5 & 0.0585 \\
\hline 13 & $\mathrm{PO}_{4}-\mathrm{P}$ & 0.65 (WPCSR) & 0.18 & 0.05 & 7.6923 & 1.3846 \\
\hline \multicolumn{7}{|l|}{$\sum W_{n}=0.998$} \\
\hline \multicolumn{7}{|l|}{$\mathrm{WQI}=\sum_{\mathrm{i}=1}^{\mathrm{n}}$} \\
\hline
\end{tabular}

Table 5: The computation of Water Quality Index of station (S2). 
Citation: Imneisi IB, Aydin M (2016) Water Quality Index (WQI) for Main Source of Drinking Water (Karaçomak Dam) in Kastamonu City, Turkey. J Environ Anal Toxicol 6: 407. doi: 10.4172/2161-0525.1000407

\begin{tabular}{|l|c|c|c|c|}
\hline \multirow{2}{*}{$\begin{array}{l}\text { Sample collection } \\
\text { times }\end{array}$} & \multicolumn{4}{|c|}{ WQI } \\
\hline Station (S1) & Grading & Station (S2) & Grading \\
\hline September 2015 & 17.76 & $\mathrm{~A}$ & 18.73 & $\mathrm{~A}$ \\
\hline November 2015 & 38.27 & $\mathrm{~B}$ & 37.56 & $\mathrm{~B}$ \\
\hline January 2016 & $\mathbf{5 3 . 9 3}$ & $\mathrm{C}$ & $\mathbf{5 6 . 7 8}$ & $\mathrm{C}$ \\
\hline March 2016 & 29.54 & $\mathrm{~B}$ & 12.27 & $\mathrm{~A}$ \\
\hline May 2016 & 27.08 & $\mathrm{~B}$ & 30.32 & $\mathrm{~B}$ \\
\hline July 2016 & 32.17 & $\mathrm{~B}$ & 32.42 & $\mathrm{~B}$ \\
\hline Mean & 35.16 & $\mathrm{~B}$ & 32.05 & $\mathrm{~B}$ \\
\hline
\end{tabular}

Table 6: Shown Calculation of WQI levels from many types of sample collection times and different sampling sites.

water to excellent water. WQI rating during this study displayed significant temporal differences (Figure 15) whereas January 2016 showed high level of deterioration at (S1, S2), this may be due to starting the winter 2016 where high contribution from runoff at downstream areas which increase of deterioration body water in the Dam. Likewise, water quality was strongly affected by agricultural and domestic uses. Therefore, priority should be given to minimizing these pollution sources to maintain or improve water quality in the watershed [31].

\section{Conclusions and Recommendation}

The current study was conducted the main source of drinking water for Kastamonu area (Turkey) for measuring quality of surface water. Water Quality index (WQI) was useful tool to obtain the right decision and evaluating water quality. This technique seems to be more systematic and offers comparative assessment of the water quality for different sampling site and different of temporal sampling. The results reveals are

- During this study the average values of WQI for two station $(\mathrm{S} 1, \mathrm{~S} 2)$ were categorized as good water quality for the human use $(35.5,32.4)$ respectively for the period from September 2015 to July 2016.

- Generally, there was significant temporal variations in water quality index among poor quality to excellent quality due to in the beginning rainfall at the winter season where runoff operation carried a lot of material such as organic material or other particles.

- The higher $\mathrm{pH}$ values were noticed during the march, that may be mainly related to the photosynthesis.

- In January 2016, the large concentration values of Ammonia, Nitrite, Conductivity and BOD were noticed within the acceptable limit of (WHO) and (WPCSR) except the averages of BOD obtained completely exceeded the Turkish standard (WPCSR) and (WHO) due to runoff from farming area at watershed of Karaçomak dam.

In future, evaluation of water quality in Karaçomak dam should be given main priority of using the microbiological parameters with physico-chemical parameters in WQI calculations and to water quality monitoring.

\section{References}

1. Bhadja P, Vaghela A (2013) Assessment of physico-chemical parameters and water quality index of reservoir water. IJPAES 3: 89-95.

2. Javid A, Yaghmaeian K, Abbasi E, Roudbari A (2014) An evaluation of water quality from Mojen River, by NSFWQI index. Journal of Ecological Engineering 15.

3. Semiromi FB, Hassani AH, Torabian A, Karbassi AR, Lotfi FH (2011)Water quality index development using fuzzy logic: A case study of the Karoon River of Iran. African Journal of Biotechnology 10: 10125-10133.
4. Whitall D, Hively WD, Leight AK, Hapeman CJ, McConnell LL, et al. (2010) Pollutant fate and spatio-temporal variability in the choptank river estuary: Factors influencing water quality. Science of the total environment 408: 20962108.

5. Taner MÜ, Üstün B, Erdinçler A (2011) A simple tool for the assessment of water quality in polluted lagoon systems: A case study for Küçükçekmece Lagoon, Turkey. Ecological Indicators 11: 749-756.

6. Davies JM (2006). Application and tests of the Canadian water quality index for assessing changes in water quality in lakes and rivers of central North America. Lake and Reservoir Management 22: 308-320.

7. Davies JM, Mazumder A (2003) Health and environmental policy issues in Canada: the role of watershed management in sustaining clean drinking water quality at surface sources. Journal of environmental management 68: 273-286.

8. Nasirian M (2007) A new water quality index for environmental contamination contributed by mineral processing: A case study of Amang (Tin Tailing) processing activity. Journal of applied sciences 7: 2977-2987.

9. Gazzaz NM, Yusoff MK, Aris AZ, Juahir H, Ramli MF (2012) Artificial neural network modeling of the water quality index for Kinta River (Malaysia) using water quality variables as predictors. Marine Pollution Bulletin 64: 2409-2420.

10. Koçer MA, Sevgili H (2014) Parameters selection for water quality index in the assessment of the environmental impacts of land-based trout farms. Ecological Indicators 36: 672-681.

11. Findik O (2013) Assessment of Metal Concentrations and Physico-chemical Parameters in the Water of Beyler Reservoir (Kastamonu, Turkey). Ekoloji 22 $51-57$

12. Elmaci A, Topac FO, Ozengin N, Teksoy A, Kurtoglu S, et al. (2008) Evaluation of physical, chemical and microbiological properties of lake Uluabat, Turkey. J Environ Biol 29: 205-210.

13. Al-Mashakbeh HM, Al-harahsheh ST (2015) The Effect of Utilizing Microbiological Parameters on Water Quality Index Values Implemented at Wadi Al-Arab Dam Reservoir, North-Jordan. Journal of Natural Sciences Research 5: 138-152.

14. Özdemir Ö (2016) Application of Multivariate Statistical Methods for Water Quality Assessment of Karasu-Sarmisakli Creeks and Kizilirmak River in Kayseri, Turkey. Pol. J. Environ. Stud 25: 1149-1160.

15. Tiwari T, Mishra M (1985) A preliminary assignment of water quality index of major Indian rivers. Indian J Environ Prot 5: 276-279.

16. Wanda EM, Gulula LC, Phiri G (2012) Determination of characteristics and drinking water quality index in Mzuzu City, Northern Malawi. Physics and Chemistry of the Earth, Parts A/B/C 50: 92-97.

17. Debels P, Figueroa R, Urrutia R, Barra R, Niell X (2005) Evaluation of wate quality in the Chillán River (Central Chile) using physicochemical parameters and a modified water quality index. Environmental monitoring and assessment. 110: $301-322$

18. Dede OT, Telci IT, Aral MM (2013) The use of water quality index models for the evaluation of surface water quality: a case study for Kirmir Basin, Ankara, Turkey. Water Quality, Exposure and Health 5: 41-56.

19. APHA, AWWA (1981) Standard methods for the examination of water and wastewater: selected analytical methods approved and cited by the United States Environmental Protection Agency: American Public Health Association.

20. APHA, AWWA, WEF (1989) Standard methods for the examination of wate and wastewater. 20th edn. American Public Health Association. Washington DC, USA.

21. Balan IN, Shivakumar M, Kumar PM (2012) An assessment of groundwater quality using water quality index in Chennai, Tamil Nadu, India. Chronicles of young scientists $3: 146$

22. Chauhan A, Singh S (2010) Evaluation of Ganga water for drinking purpose by water quality index at Rishikesh, Uttarakhand, India. Rep Opin 2: 53-61.

23. Tyagi S, Sharma B, Singh $P$, Dobhal $R$ (2013) Water quality assessment in terms of water quality index. American Journal of Water Resources 1: 34-38.

24. WHO (2011) Guidelines for Drinking Water Quality. 4th edn. World Health Organization, 20 Avenue Appia, 1211 Geneva 27, Switzerland.

25. Ahmad AB (2014) Evaluation of Groundwater Quality Index for drinking purpose 
Citation: Imneisi IB, Aydin M (2016) Water Quality Index (WQI) for Main Source of Drinking Water (Karaçomak Dam) in Kastamonu City, Turkey. J Environ Anal Toxicol 6: 407. doi: 10.4172/2161-0525.1000407

Page 8 of 8

from some villages around Darbandikhan district, Kurdistan Region-Iraq. IOSR Journal of agriculture and veterinary science $7: 34-41$.

26. Yogendra K, Puttaiah E (2008) Determination of water quality index and suitability of an urban waterbody in Shimoga Town, Karnataka. Paper presented at the Proceedings of Taal 2007: The 12th World Lake Conference.

27. Lachhab A, Beren M, Zuidervliet B (2014) Middle Creek Water Assessment Using Water Quality Index (WQI). Journal of the Pennsylvania Academy of Science 88: 4-12.

28. Kagalou I, Economidis G, Leonardos I, Papaloukas C (2006) Assessment of a Mediterranean shallow lentic ecosystem (Lake Pamvotis, Greece) using benthic community diversity: Response to environmental parameters. LimnologicaEcology and Management of Inland Waters 36: 269-278.

29. Yisa J, Jimoh T (2010) Analytical studies on water quality index of river Landzu. American Journal of Applied Sciences 7: 453.

30. Kutlu B, Sesli A, Tepe R, Mutlu E (2015) Assessment of Physico-chemical Water Quality of Birecik Dam, Şanlıurfa, West East Region, Turkey. Turkish Journal of Agriculture-Food Science and Technology 3.

31. Boyacioglu $\mathrm{H}$ (2007) Development of a water quality index based on a European classification scheme. Water Sa, p: 33. 